Pobrane z czasopisma Annales H - Oeconomia http://oeconomia.annales.umcs.pl Data: 26/04/2023 11:54:52

DOI:10.17951/h.2015.59.3.155

\begin{tabular}{lcl}
\hline \multicolumn{1}{c}{ A N N A L E S } \\
UNIVERSITATIS & MARIAE CURIE-SKŁODOWSKA \\
LUBLIN - POLONIA & SECTIOH H \\
VOL. XLIX, 3 & 2015 \\
\hline
\end{tabular}

University of Management and Administration in Zamość, Faculty of Management and Administration, Department of Finance and Accounting

ILONA PETRYK

ilonapetryk@yahoo.co.uk

\title{
Outsourcing Strategy in Network Enterprises
}

Strategia outsourcingu w przedsiębiorstwach sieciowych

Keywords: strategy, outsourcing, outstaffing, staff leasing, entrepreneurship.

Slowa kluczowe: strategia, outsourcing, outstaffing, leasing personelu, przedsiębiorczość.

JEL Code: M21

Outsourcing, outstaffing, and staff leasing are services increasingly becoming the subject of discussion among top managers of leading companies. An increasing number of providers declare their readiness to provide such services on the Ukrainian market of skilled labor. However, we must acknowledge that providers and customers of these types of service demonstrate fairly broad differences in the understanding of the nature and content of each of such services. In using the same terms, they often put them in different content. Requesting, for example, leasing services, customers often involve outstaffing, and the other way around. That is why it is so important to explain the idea of outsourcing.

\section{Outsourcing and insourcing}

Insourcing means assigning a project to a person or department within the company instead of hiring an outside person or company to do the work. While outsourcing is commonly thought of as a way for companies to save money, it is sometimes more 
cost-effective to have the work done in-house (Investopedia, dictionary). Insourcing is possible in companies that have the ability to provide for themselves a qualified personnel. Preferably, insourcing is found in large enterprises that have employees qualifying in various types and are able to perform the full range of work included in the production process of the company. Outsourcing is more common in SMEs that do not have enough qualified enterprises in the whole spectrum of work.

\section{Types of outsourcing: the nature and characteristics}

The growing popularity of outsourcing in USA was due to tighter competition and the need to find effective long-term strategies for sustainable organizational advantage. In the early 1980s, Western companies have suddenly realized that consumers are not the only thing for business entities to rival for. Struggle for quality of manpower became one of the areas of competition. Limited supply of truly effective professionals, dynamically changing needs for new knowledge and skills of professionals have given the popularity of the idea of organizational structures, in which the attention is focused on the main staff. These are the key professionals, the amount of experience, knowledge and skills that make an organization different from the others. They are vital, they are very difficult to replace and in case they leave, the company can simply go bankrupt. These professionals made diligent work for long hours for the sake of fulfilling the obligations assumed by the welfare business. They were no longer the same people who worked 40 hours a week for a year. Business owners understand that the security of the business depends on the ability of the organization to keep these professionals close. Since they receive social security and all sorts of benefits, they become very expensive workers (Bilous, 2010, p. 245).

It is clear that no single company could effort to pay for work of a large number of employees. Therefore, the number of company's workers was constantly decreasing. The main part of work was increasingly carried out by those who have signed a temporary contract with the company and were ready to do the job with the appropriate quality, but at a lower price. In turn, the owners of the company believed that it is unreasonable to provide additional benefits to people who are not the main workers of the company. The next step in the development of this trend was the idea of outsourcing functions to units the activity of which was not primary for the full implementation of the company's core competences. Following the first attempts to introduce effective outsourcing leading companies, stable demand for agency non-key employees was formed. Demand, as always, gave birth to an offer.

The first to place a bid were companies that specialized in recruitment. It was the easiest way to create a team that would have roamed from company to company, realizing more or less similar projects. These companies could functionally and technically transform their business into services that other companies needed. 
Other content services allowed to differentiate some of its subspecies and that way leasing personnel (staff leasing), removal of personnel for the staff (outstaffing) and recruitment of temporary staff (temporary staffing) became narrow, specific manifestations of outsourcing.

Leasing staff means the use of borrowed staff permanently employed by the company provider by the customer's company. That means the customer buys the service to perform work, not the work of individual employees. As a rule, the terms of the lease meant work that was necessary to maintain life-support of the company, but not directly generated income. Company-lessee was free from the additional costs of search and selection of the necessary personnel. It was not necessary to enter into a separate contract of employment with the employee. A company could refuse the services of an employee at any time and did not think about compliance with the requirements set forth by legislation in relation to the dismissal of personnel and their social protection. They would not be concerned with the employee's period of work experience, pension payments, problems associated with personnel documentation, professional growth, and development of leased personnel. At the same time, but not realizing the selection of employees hired, the company could not affect the number of their personal and professional qualities. Shutdown in temporary employer for the employee was not ground for termination of his employment relationship with the company provider, which is his permanent employer. Company-lessor has been a source of corporate culture, digestible by employees.

So as the company was profitable to provider borrowed employees, the demand for them has to be stable enough: it would exclude the long downtime between projects specialists from different employers.

Outstaffing positioned as a service for the withdrawal of existing staff from the company. This approach was used in situations where the client company could not increase the number of employees for various reasons. Enrollment of workers of the network provider became a tool to adjust the number of personnel without changing the actual number of staff of the client company. That company provider became a formal employer and came in relation with employees in compliance with all local laws. The employer calculated and paid wages, and made all the necessary deductions for taxes and social contributions. On request, the provider assumed the full administration of missions, the conclusion of all kinds of insurance contracts (thereby ensuring staff health insurance, life insurance, accident insurance), provided the official transport, means of communication, and services. The list was limited only to the customer's needs in administrative support, economic feasibility and the objective possibilities of the company - the service provider (Outsourcing technology, 2005).

The third type of outsourcing services is selection of temporary staff. It was designed to meet the need of companies in "flexible" workforce by providing workers on a part-time or short-term (from one day to several months) basis. The demand for these workers grew very quickly. Part of this increase was due to rapid devel- 
opment of services for producers (for example the delivery of products to stores or by selling it directly to the consumer). Such stuff, in contrast to the producers, was not able to create significant reserves of finished product. Therefore, it was necessary to increase the pace of its turnover, adjusting to the natural burst of consumer activity. In order to meet the growing needs effectively and in a timely manner for both customers and manufacturers, who were interested in increasing sales, the company offers services that enter into contracts for the periodic maintenance of additional workers.

Economic and organizational effectiveness of outsourcing schemes showed positive results enabling companies to be more flexible and faster in responding to the new challenges of the competitive environment. Studies show that up to $80 \%$ of value added in the loan taken by people in some companies had different forms at different times in the value of final goods or services (Central and Eastern Europe IT Outsourcing Review, 2013).

All types of outsourcing are effective on horizontal and vertical structure of enterprises.

\section{Peculiarities of Ukrainian outsourcing: who buys and why?}

Outsourcing is in formative stages in Ukraine. The General Directorate for Foreign Missions Service is the pioneer of outstaffing. By the end of 1990, recruitment agencies began to provide outstaffing service. Their first customers were also Western companies with experience of such cooperation in their countries. The choice of recruitment agencies as the most popular service providers of outstaffing is due to the fact that the company has cooperated with them in searching for staff, and therefore trusted them to be reliable partners (Chukhray, 2007, p. 33).

The impetus for the increased demand for outstaffing was certainly the prolonged stagnation of business activity that followed the 1998 crisis. The head offices of foreign companies, seeing a decrease in sales volumes, made decisions on the reduction of staff in regional offices, often without reducing the production of implementation plans for the following periods. There is a paradoxical situation: resources activities were removed and the amount of work even increased. Then it was generated by a virtual reduction in which staff was transferred to the staff of the companies - providers of outstaffing service. Sometimes, due to a temporary reduction in the need for formal staff, staff transferred to the company of the provider, and then, at the request of the customer, the same experts came back to the company of the real employer.

Foreign missions without formal permission for sale that are restricted by law, found a way out in the formal derivation of employees in the state of the same recruiting companies.

Next, stimulant demand for the service of outstaffing laid in main offices, imposed restrictions. There is a so-called corporate headcount or staff number limit 
in a country or some volume of business in this country. If the company maintains or even increases the required minimum, the local offices have to seek permission to hire outstaffing resources, in order to cope with the assigned labor obligations.

Sometimes the outstaffing service is requested by Western companies entering the market of Ukraine. For them, the delay is often a desirable legalization of their legal status. As a rule, in the first year, when business prospects are still very uncertain, many are hesitant to invest in opening a full representation. However, some activities, such as market research market on opportunities are necessary. Then either services of a person with the status of a private entrepreneur or company are used to outsource a comprehensive service in the sustenance of office in the new territory. Contents of the package may have a different amount of filling: office rent, office equipment and communications equipment, vehicles, computer network maintenance, logistics, market research, search and selection of personnel, recruitment consultancy, HR administration and payroll staff employed with full tax support. Legal services in the area of Human Resources act as the provision of outstaffing services.

The first area of increased interest in domestic companies is related with HR managers which are looking for effective ways of reducing the cost of business and rightly see them in bringing their employees in the company providers. It is indeed possible, if the provider uses preferential tax treatment, for example, is a single tax payer. Staff then reduces the cost for the customer. However, it is only possible in cases where the turnover of the provider does not exceed the limits of legislation and if the provider is willing to pay the minimum wage, leaving the actual employer to pay any amount, passing them through the legalization of payroll. If the service provider was originally fully transparent and provided a full range of opportunities for additional compensation, allowances, benefits and general administrative support staff, then its value clearly exceeds the costs incurred by the company in self-employment, in the amount equal to the amount of the fee recruitment agency plus VAT. Financially measurable benefits consist in the release of the service personnel and finance department of the client from a certain amount of administrative and financial paper work to reduce the risks inherent in the dismissal procedures, the opportunity to address the issue of permanent employment test the employee for the time much longer than standard probation (Favre et al., 2004).

The second area of increased interest in domestic companies is the ability of outstaffing employees to perform work with potentially high risk of occupational injuries. Such service providers agree to provide a very well-developed system of risk minimization. This implies the existence of a state network provider of qualified specialists on labor protection, regular events to instruct staff and cooperation with the conscientious and experienced insurers. If the provider does not find a host of resources to minimize such risks and at the same time meets the client's refusal to find professionals who are able to provide this minimization, this represents the decision to refuse the provision of outstaffing services most adequately. 


\section{Conclusions}

In conclusion, we can state that outsourcing is an important part of the economy of each country. Development of outsourcing in Ukraine helps companies to conduct their business efficiently and with better results for the company. Outsourcing, in all its forms, creates added value for the company and helps to save time by using skilled labor.

\section{References}

1. Bilous O., Global competitive outsourcing. Kyiv, Kyiv National Economical University, 2010.

2. Central and Eastern Europe IT Outsourcing Review 2013, http://ceeoa.org/news/ceeoa-news/centralandeastern-europe-it-outsourcing-review-2013/

3. Chukhray N., Outsourcing in logistics: European and Ukrainian experience, Transport and logistics, 2007, Vol. 19, No. 5.

4. Investopedia Dictionary, http://www.investopedia.com/

5. Favre D., Findley Ch., Zanker J.C., What Is Procurement Outsourcing?, 2004, www.supplychainplanet. com

6. Outsourcing technology: guidelines for establishing sourcing partnerships that are effective and truly strategic, Industrial Research Institute Inc, 2005, http://www.highbeam.com/doc/1G1\#132299620.html

\section{Outsourcing Strategy in Network Enterprises}

Abstract. The purpose of this article is presentation of outsourcing strategy formation in enterprises networks. The analysis of factors affecting outsourcing strategy training in enterprises networks are showed in the article. Specificity of outsourcing strategy compared with insourcing strategy in integrated companies. The role of business outsourcing process in developing strategies for vertically and horizontally integrated companies is described. The research on implementation policy of outsourcing strategy in network companies on the example of companies in Ukraine is analyzed as well.

\section{Strategia outsourcingu w przedsiębiorstwach sieciowych.}

Abstrakt. Celem artykułu jest formowanie strategii outsourcingu w przedsiębiorstwach sieciowych. W artykule jest przeprowadzona analiza czynników wpływających na kształcenie strategii outsourcingu w przedsiębiorstwach sieciowych. Pokazana została specyfika strategii outsourcingu w porównaniu ze strategią insourcingu w przedsiębiorstwach zintegrowanych. Określono role procesów biznesowych w tworzeniu strategii outsourcingu dla pionowo i poziomo zintegrowanych przedsiębiorstw. Przeprowadzono badania wdrożenia strategii outsourcingu w przedsiębiorstwach sieciowych na przykładzie przedsiębiorstw na Ukrainie. 